\title{
Conversational Style of Male and Female Characters in Game of Thrones Season 8
}

\section{Gaya Percakapan Aktor dan Aktris dalam Game of Thrones Season 8}

\author{
Tati Khumairoh, Mirjam Anugerahwati* \\ Universitas Negeri Malang, Jl. Semarang No. 5 Malang, Jawa Timur, Indonesia \\ *Penulis korespondensi, Surel: mirjam.anugerahwati.fs@um.ac.id
}

Paper received: 01-05-2021; revised: 17-05-2021; accepted: 31-05-2021

\begin{abstract}
This study aims to find out what are conversational features used by male and female characters in Game of Thrones season 8, how it is represented in their conversation, and how power and social status affect characters' linguistic behavior. This study used a descriptive qualitative research design. The data of this study are twenty-two conversations taken from episode 1 up to episode 6 of season 8. There are four conversational style features discussed in this study: (1) talkativeness, (2) interruption, (3) compliments, and (4) minimal responses. The results show that all four features are found in the conversations, but they are manipulated differently by male and female characters. Also, the use of gender conversational style features in this case seems universal. Female characters are more talkative which confirms the theory of women's language. Male characters also use female conversational style more frequently in terms of minimal responses and compliments. However, power plays an important role in this case since it enables characters to be more dominant which reflects that gender is not the only factor to control the conversation.
\end{abstract}

Keywords: compliments, conversational style, interruptions, minimal response, talkativeness

\begin{abstract}
Abstrak
Penelitian ini bertujuan untuk mengetahui gaya percakapan yang digunakan oleh pemeran pria dan wanita dalam serial berjudul Game of Thrones Season 8, bagaimana gaya tersebut direpresentasikan dalam percakapannya, dan bagaimana kekuasaan dan status sosial mempengaruhi perilaku linguistik karakter. Penelitian ini menggunakan desain penelitian deskriptif kualitatif. Data dalam penelitian ini adalah dua puluh dua percakapan yang diambil dari episode 1 hingga episode 6 di season 8. Ada empat fitur gaya percakapan yang dibahas dalam penelitian ini: (1) tingkat keaktifan berbicara, (2) interupsi, (3) pujian, dan (4) tanggapan minimal. Hasil penelitian menunjukkan bahwa keempat fitur ditemukan dalam series ini, namun dipraktekkan secara berbeda oleh karakter pria dan wanita. Selain itu, penggunaan fitur gaya percakapan gender dalam hal ini terkesan universal. Karakter perempuan lebih banyak bicara yang mana mendukung teori gaya bahasa wanita. Karakter pria juga lebih sering menggunakan gaya percakapan wanita dalam hal memberikan tanggapan minimal dan pujian. Namun, kekuasaan memainkan peran penting dalam hal ini karena memungkinkan karakter lebih dominan dan menjelaskan bahwa gender bukan satu-satunya faktor yang mengendalikan percakapan.
\end{abstract}

Kata kunci: gaya percakapan, interupsi, respon minimal, pujian

\section{Introduction}

The analysis of language regarding its variety, meaning, and other issues is growing continually. In this context, language is generally shaped by society. A society differentiates gender using the description of their nature. Gender is a social category. While, sex refers to the biological distinction between male and female, then gender itself is social behaviors with the nature of social behavior determining the characteristics of being feminine or masculine and that our society often projected women's talk as something negative and does not make sense 
(McElhinny, 2014; Sunderland, 2006). It can be in the form of expectations of attitudes about being masculine or feminine. There is also a notion about verbal aggressiveness between men and women as Bjorkqvist and Niemela (1992) have shown in their study that boys and girls are different in terms of aggressiveness. In particular, boys are believed to be more aggressive physically while girls are more aggressive in verbal communication.

The cultural characteristics attributed to sex are cultural construct, socially defined, and changeable (Wodak, 1997), while Gu (2013) in her study believes that the social control may prompt the various style of talking across gender. Therefore, it is obvious that social construction shapes the conversation style of genders.

Following Wardhaugh and Fuller (2015) exploration, the main issue in sociolinguistics is the interplay between language and society especially with respect to how we understand how language structure functions in a communication. That is why there is a strong relation between gender and language with the debate revolving around gender differences (Litosseliti, 2006). Language is seen as a social practice to differentiate men and women. It is also implied in social behavior such as attitude change, social perception, personal identity, interaction, bias, and stereotyping, and others (Krauss \& Chiu, 1998).

According to Louazani (2015), the difference between men and women in speech can be seen as constructing and performing gender and sexual identity. He drew the linguistic behavior of men and women in their society through their speech. This difference can be a social phenomenon done by men or women regarding their attitude and there must be reasons behind it.

The reason might be varied; it can be because of the higher social power of men through their more noteworthy inclination for the interference and their lesser commitment in interactional support in the group discussion (Bucholtz, 2003). In any community men and women still do not speak in the same way even though there are some communities in which language is shared by both genders, the difference still exists (Holmes, 2013). Within an urban society in which gender roles in society are overlapping, the language style also overlaps. The difference is in the quantities and frequency of the speech as Holmes (2013) has brought up.

In this research, the researcher explores the conversational style features of the characters in Game of Thrones Season 8. This series is popular since it presents a deep fantasy world with smart lyrical language and plot. According to the most popular movie website (IMDb, n.d.), this TV series gained more than 90\% likes rating from the audience. The researcher believes that this series can be potentially explored as a field to understand the representation of social life as stated by Shrum (2002) that television and movies are the ideal portrayal of western society.

Style can be the result of automatic linguistics cues which are natural and self-made (Suyapit, 2017). Even though the speech style is generally spontaneous and natural, there must be a motive behind the style chosen. Tannen (2005) describes the term conversational style as a semantic process showing the way meaning is derived from speech. It also referred to all aspects of a person's behavior usually thought of as personality. However, there are aspects that influence someone to behave in a certain way.

A survey conducted by Hannah and Murachver (1999), for example, has shown that conversational style between genders is substantially different. Women have goals in building 
confidence, gaining trust, and engaging in a conversation, while men are characterized as less cooperative but eager to control the floor. However, the world has changed rapidly through the years. These statements might no longer be valid in our society. The social structure between men and women is changing, thus the language style might be changing too.

\section{'Talkativeness}

Women have been said to be more talkative than men during the discussion or conversation (Bonvillain, 2007; DeFrancisco \& Palczewski, 2007). This stereotype also originated from the notion that women are more emotional and express their feelings more by talking. Later on in the findings, to measure the level of talkativeness, the researcher will rely on the word count and analyze who initiated the conversation.

\section{Interruptions}

According to Tannen (2005), there is a supportive and a disruptive interruption in a conversation. If someone violates turn-taking norms by giving positive comments or repeating the interlocutors' phrase, it can be considered as an expression of support toward a given idea and a collaborative conversation. Otherwise, if the interlocutors violate the turn-taking norms by interjecting the idea or ignoring the speaker by bringing up a completely different idea, that is disruptive and intrusive. The latter kind of interruption is clearly a way of showing power.

\section{Compliments}

Women are seen as the one who receive and give compliments more often; however, men and women give compliments in different patterns (Holmes in Coates, 1998). Women see compliments as something positive and even sometimes achievement while men see compliments as something that can build solidarity.

\section{Minimal Responses}

Zimmerman and West (1975) in their major study labelled short sounds such as uh-uh, $\mathrm{mm}, \mathrm{hmm}$, yeah as a minimal response. There are rules that define minimal response: it is not a turn, it is not to answer a question and or to get the floor.

However, social status is one of the factors that influence the way character speaks with the other sex. Someone generally behaves depending on the situation and whom they talk to. In certain contexts, gender acts as a diffuse characteristic and situation-dependent behavior; they can change their style depending on the age, level of education, culture, status, context etc (Eriksson, 2008; Carli, 1990; Fitzpatrick et al., 1995). Therefore, it is important to look at someone's social status and power to understand their conversational style deeper.

It is believed that gender conversational style is gender neutral (DeFrancisco \& Palczewski, 2007), meaning that today men might speak like women or vice versa. However, it cannot be generalized because certain special features have been proved by researchers to be used more frequently by women or men.

In investigating the language in the movie, it is obviously important to consider that the script is consciously written by the writer and not an actual conversation. Therefore, the scriptwriters' social background might, to a certain degree, influence their writing. In the season investigated, the script was written by David Benioff. He is a married man and, therefore, a 'straight'. In this way, the researcher strongly assumes that he wanted to express his gender identity through the script writing practices. His writing might convey a message 
about gender equality that already existed in the medieval era, but it cannot be overgeneralized to all movie writers. However, the point of this research is to see the representation of gender conversational style in a movie and how power and social status give effects on it.

Not many researchers did linguistic research on Game of Thrones; rather they do literary research such as the one which is conducted by Rahayu (2018) where she pointed out that the female character even in the medieval era can compete male characters and break the stereotype.

The interplay between language and gender has extensively been studied with the mainstream views covering the deficit theory by Lakoff (1973) and the dominance theory by Thorne and Henley (1975). However, the theory of language and gender implemented in this particular series is not yet studied. Therefore, what this research tries to discover in this field is the conversational style displayed in cross-sex conversation and the role of power in such social practices. To the best of the researcher's reading, there are three previous studies relevant to the investigated topic. Krauss and Chiu (1998) in their exploration maintained that language overruns social activity. Language is involved in the greater part of phenomena and at the heart of social psychology including mood change, social cognition, personal identity, social contact, intergroup bias, and stereotyping. The study focused on language usage rather than language structure. They do, however, agree that language is a culturally based context that pervades social life. Valeeva (2014) investigated how linguistic conduct in the multiethnic culture is affected by several social factors: the necessity of improvement of linguistic behavior as a powerful social and cultural potential of the population. From here, the researcher found the same idea about how the relationship between the social and language applied and analyzed by the previous researchers. Shopi (2015) examines women's speech where she analyzed the way of speaking defined as "the rhetoric expression" and "subversive speech strategies". Her study found that women's attitude in speaking describes their position and social status, and that the importance of gender relies heavily on a certain environment.

From the previously mentioned potential research gaps, the most needed future studies to conduct are those focusing on the conversational style of men and women in comparison. That is why, it led the researcher to find out what are the conversational style features used by the characters, how they used it, and how social status influences their behavior.

\section{Method}

In this study, the researcher uses a descriptive qualitative method. The researcher believed a qualitative method is the most suitable method to obtain a deep understanding of the data, which is the movie-dialogue transcription. Since it is a form of systematic empirical inquiry, it is based on the researcher's experience (Shank, 2002). Qualitative data allows researchers to be far more speculative about what areas were chosen to investigate and how to do so. Qualitative research is a form of interpretive inquiry in which researchers make an interpretation of what they see, hear, and understand (Creswell, 2014). This method will be advantageous due to its sufficiency to bring the researcher's thoughts into the data analysis.

The researcher's data are twenty-two chosen cross-sex conversations from the series titled "Game of Thrones, Season 8". Cross-sex conversation was chosen in order to compare male and female characters in the discussion; it enables the researcher to see the motive of their style in a certain speech situation. Game of Thrones is an American fantasy drama adapted from a novel titled "A Song of Ice and Fire", a series of fantasy novels by George R. R. Martin. 
Season 8 has 6 episodes; each episode has at least an hour duration which is the peak of the series with many intense conversations. The researcher notices the changing behavior of the characters throughout the whole season; and social status is one of the factors that influence the language style of the characters. That is why the researcher chose the last season to be analyzed. Besides, the researcher believes that linguistics behavior in terms of conversational style will be more obvious in this season.

To minimize the invalid data, the researcher employed observation methods in collecting the data. Muhammad (2011) states that observation technique is a strategy to get the information by noticing the utilization of language. First, the researcher watches the movie thoroughly and then takes a note the conversational style features that exist in the cross-sex conversation, that is why not all cross-sex conversation are taken as data. However, it is also possible to take a feature from same-sex conversation. In this present study, the researcher transcribed the chosen dialogues by herself as also to identify certain linguistic-behavior that represents the characters' style and the language features used.

To answer the problems of the study, some steps were conducted. After collecting the data, the researcher then analyzes the data by firstly identifying gender conversational style features used by the characters, and identifying how a conversational style is used as a communication strategy in the dialogue. The researcher identifies the result of the first step to see the social status embedded in the characters. As the status can determine speakers' style, it lets the researcher know the dominant party in the conversation and its relation to the power they have.

\section{Findings and Discussion}

In this part, the researcher analyzed four conversational features mentioned before and explained the social status of the characters that may give significant effects to the chosen expression.

\subsection{Talkativeness}

In terms of talkativeness, the researcher took nine conversations with approximately 100 up to 300 words each. In terms of word count, female characters have a greater number in six out of nine conversations. However, it needed to look at the initiator and who brings up more topics in the conversation. With regard to the conversational style, the researcher found that there are four conversations discussing intimate relationships and emotional topics. In these four conversations too, male characters are more talkative in two conversations and the two remaining are female's talkativeness. Not only about relationships and emotional topics, there are also conversations about the war and its strategy. It is interesting that from nine cross-sex conversations, women are more talkative when they are discussing about the war and its strategy. The researcher found that there are four out of five conversations about the war in which women tend to be more talkative and dominating the floor. It means that men were only once more talkative when they discussed the war.

From the nine data of talkativeness, below are the conversations that show men are more talkative when they are discussing emotional topics: 


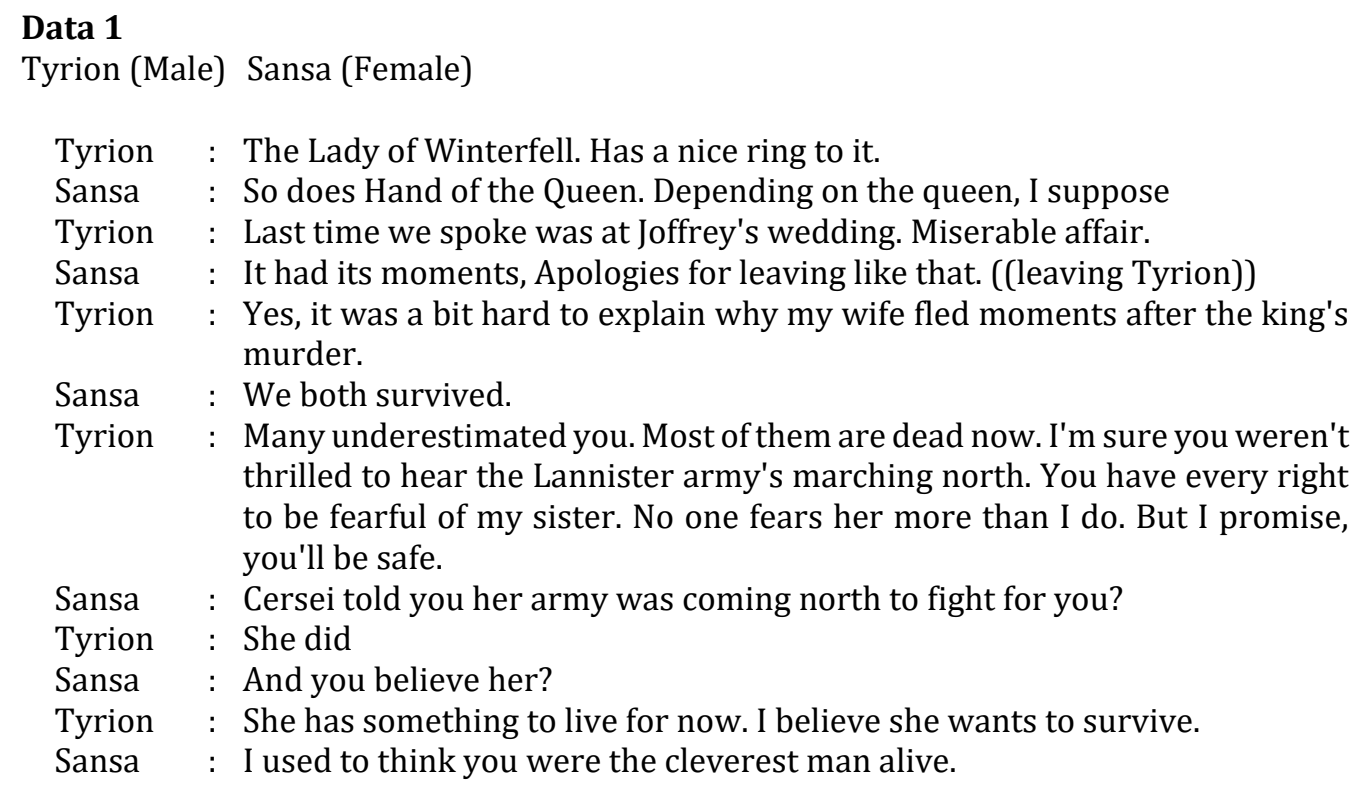

This conversation was situated in Winterfell where Sansa and Tyrion reunited after a long time being separated. Data 1 shows that Tyrion is more talkative than Sansa. He speaks 97 words while Sansa only speaks 50 words. Tyrion talked about the last time he met Sansa and tried to discuss their relationship, however, Sansa seemed to refuse it by saying "It had its moments, apologies for leaving like that" after that Tyrion was still trying to make the conversation longer but Sansa replied "We both survived" and wanted to leave him. It is clear that Sansa did not want to talk about their relationship anymore, and made Tyrion shift the topic about the war.Talking about the relationship of the speakers, it might give some explanation on how their conversation was going on. Sansa was Tyrion's wife, they were married and arranged by the Queen and basically, they did not love each other. In this conversation, Tyrion is more talkative maybe because he needs explanation on why Sansa left him in the past but Sansa seems to not want any more interaction with her past. That is why Sansa is more silent within the conversation.

The same thing is reflected in Data 2 (see appendix). The conversation happened after Euron brought 20.000 armies for Cersei to fight the war and then he asked for the reward that Cersei had promised. He tried to get Cersei's attention by saying flowery words "How? I've given her justice, an army, and the Iron Fleet yet she gives me no sign of affection. My heart is nearly broken". The male character, Euron, is more talkative in this conversation. Euron speaks 53 words and Cersei only speaks 38 words. The researcher found the same pattern regarding the relationship aspect in the two data. Cercei does not love Euron, she only takes advantage of him. That is why it is Euron who is chasing Cersei's attention by talking a lot. The two conversations show that the women have difficulties engaging in emotional conversations and it is always the men who load emotional matters. The previous theory about women's talkativeness regarding their emotional being (Bonvillain, 2007; DeFrancisco \& Palczewski, 2007) is no longer valid in this particular finding.

In the last season of Game of Thrones, both female and female characters have the dominant roles in the story, but at different levels of social status. It makes sense that female characters are also actively participating in important discussions such as war and its strategy. Below are the conversations that show women are more talkative than men in the serious discussion: 


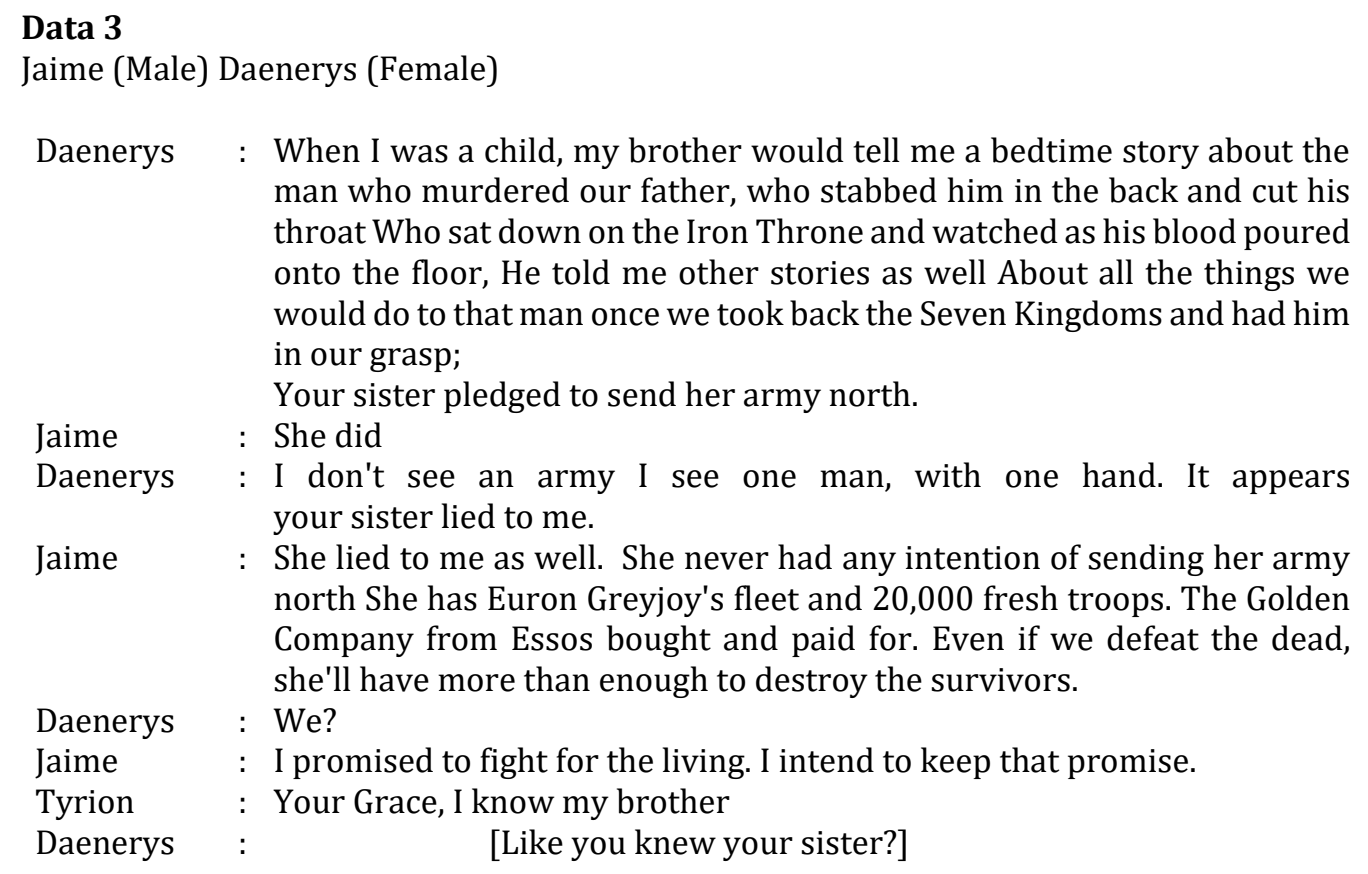

This conversation happened when Jaime, the enemy who wanted to fight the White Walkers (army of dead people) was caught and considered to be executed. The conversations started by Daenerys and there were ladies and gentlemen. Daenerys talked more than the male character in this conversation; she had 109 words and interrupted once, while the male characters only spoke 72 words. It breaks the stereotype that females are not allowed to participate in the serious discussion because they are not capable, as Sunderland (2006) has brought up. It is possible that Daenerys was talkative since she was talking to her enemy inferior; their relation affects the conversation. The same thing happened to Data 4 (see appendix) where female characters are more talkative when discussing the war. In the Data 4, Arya, the female character who has a high status in Winterfell but she is also a friend to her interlocutor, Gendry. Their relationship and Arya's status enable her to be more talkative during the conversation.

With respect to talkativeness, female characters in the data often tend to be more talkative that these findings provide support to the previous studies such as Sunderland (2006). However, the researcher assumes that they are more talkative in a serious discussion rather than in emotional discussion as shown in the data.

As aforementioned, this season is the peak of the show that caused only significant characters to remain. The female characters are the Queen, Lady, future queen, other important roles, while the male characters are Lords, Hand of the queen, and most of them have a high social class in the community. The female characters have rights and power to speak with men including the serious discussion (Shopi, 2015; Valeeva, 2014). As in the Data 1 and 2, the male characters are more talkative in the intimate and personal discussion. While the female characters are seemingly not interested in the conversation, they are more interested in the serious discussion as reflected from the level of their talkativeness. The researcher assumed that female characters in this movie are preserving their high status as Queens or ladies. Therefore, power and social status play a more important role rather than gender. 


\subsection{Interruption}

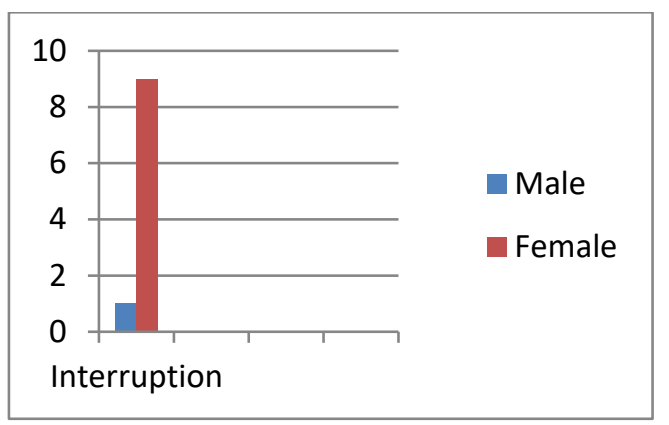

Figure 1. Interruption in cross-sex conversation of Game of Thrones Season 8

The researcher found that out of twenty-two conversations, ten of them contained expressions of interruption. As the diagram shows, it appears that female characters interrupted more often in the cross-sex conversation. The margin is obvious, there is only one interruption made by a male character and nine by the female character. To this extent, this research did not confirm the previous theory that state men interrupt more than women did.

Based on the data taken from season 8 of Game of Thrones, it cannot be denied that female characters are more dominant in speaking. It also applies to interruptions. There are also factors that might affect interruption, such as the intimacy between the speaker, the context, and the community of speaking. That is why in this research, the researcher will consider those elements in the movie.

There are ten interruptions found in the cross-sex conversations and nine of them are done by female characters. As in Data 1,3, and 4 above there are interruptions made by female characters. In Data 1, Sansa interrupted Tyrion and directly addressed a question to him.

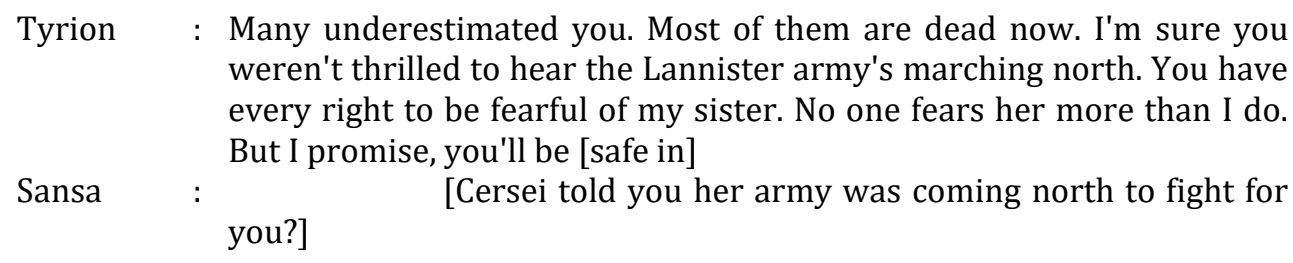

In interrupting Tyrion is undoubtedly fine and acceptable according to her. The conversation happened in Winterfell, where Sansa is the Lady of the house and Tyrion here as her guess. It makes sense that she thought she is more superior than Tyrion even though he is the hand of the queen Daenerys. The female character in this conversation has power in determining the interruption and controlling the topic. Again, it is important to note that gender may not be the only determining factor that controls the conversation, but there may be many other factors. It confirms the idea pointed out by Eriksson (2008) that gender is not the only thing that controls the conversation.

There is also another reason behind interruption made by female characters as in Data 3. In this conversation, Daenerys interrupted Tyrion who is going to defend his brother, Jaime, so that he is not executed.

$\begin{array}{llr}\text { Tyrion } & : & \text { Your Grace, [I know my brother] } \\ \text { Daenerys } & : & \text { [Like you knew your sister?] }\end{array}$ 
Daenerys interrupted Tyrion to remind him about the mistake of believing his sister Cersei. This interruption is also made to avoid him talking more and to block his right to speak. Data 1 and 3 happened between the superior party and the inferior party. The female characters in the two conversations have a higher status and position than their interlocutors. That is why they can say anything they want including interrupting. The violation of turntaking norms in the conversation gives a high-status party access more interpersonal and the floor of the lower-status speakers. So, interruption here can be determined as actual dominance and a way to accomplish power in the conversation.

There is one case male character interrupts a female. The male character, Jon, interrupt his sister Sansa in a family discussion:

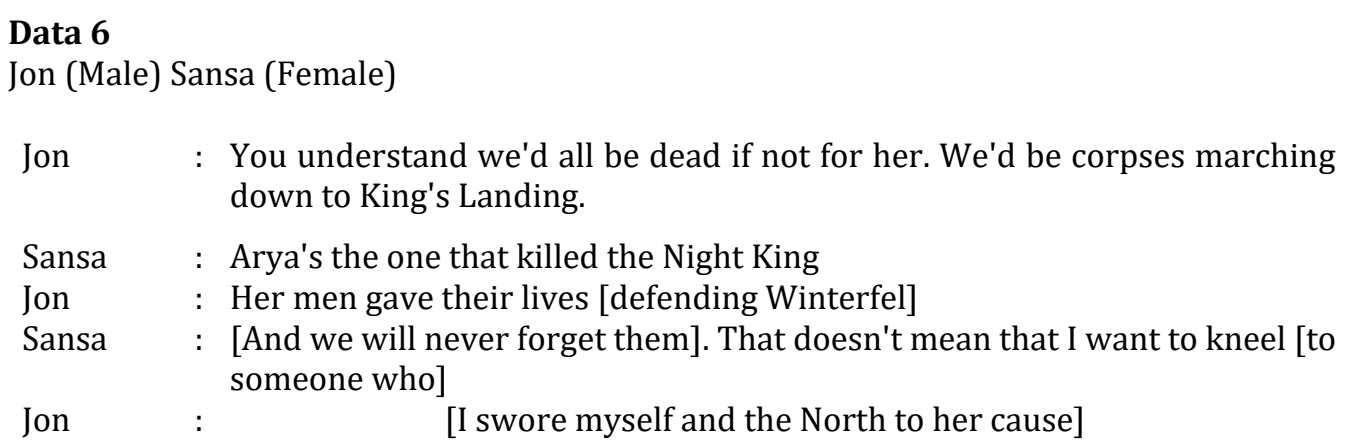

This conversation happened between Jon, Sansa, Arya, and Bran. They are siblings in the Winterfell. They were talking about Jon being biased to queen Daenerys rather than his family. In this conversation both male and female characters are interrupting. It makes sense that male character interrupts since he is talking to his sister. In this way, it supports the researcher's previous statement that social status affects how someone speaks. In this conversation, all speakers have the same social status which enables them to speak without fear.

Regarding the power of the interrupters, it is clear that high-social status characters tend to interrupt the discussion and grab the floor. Their power gives the right to interrupt the lower-status interlocutors. In this movie, female characters are the ones who are interrupted more. It shows that women in this movie break the stereotype that men are more likely to interrupt and dominate the floor as in DeFrancisco and Palczewski (2007).

\subsection{Compliments}

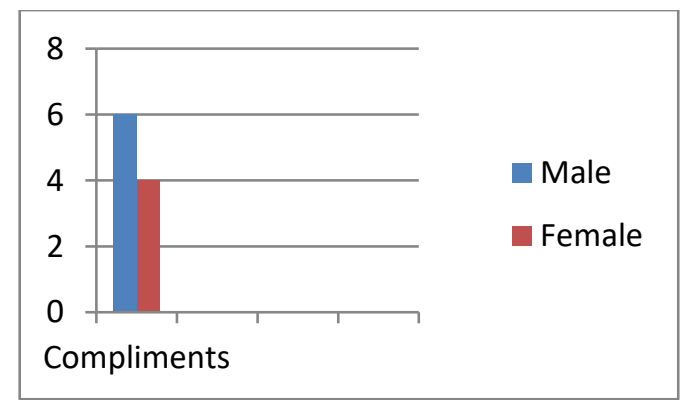

Figure 2. Compliments in the conversation of Game of Thrones Season

The researcher has difficulties in finding compliments only in cross-sex conversation. Therefore, the researcher takes all the compliments through the season: cross-sex compliments, male-male compliments, female-female compliments, to gain a larger number of 
data and found eleven obvious compliments. The result is interesting because the margin of compliments uttered by male and female characters is not big. However, the number of compliments uttered by male characters is higher than female.

The main function of complement is to build solidarity between the addresser and the addressee (Herbert, 1990). However, there might be something else behind compliments such as being sarcastic. The stereotype about compliments in society is that women love to be complimented and they value compliments as something positive, sometimes achievements. That is why it was found that women give and receive compliments more than men.

Based on the data collected, the male characters give more compliments than the female characters. The difference of compliments made by male and female characters lay in the forms of the topic, function, and the way they address it. It is found that male and female characters are giving compliments about something differently. Men tend to compliment others about their skill and accomplishments rather than appearance and personality. On the other hand, female characters tend to give compliments regarding the appearance and personality, the result is as follow:

Table 1. Topic of compliments

\begin{tabular}{lccc}
\hline & \multicolumn{2}{c}{ Topic } & Total \\
\hline Male & Appearance & Skill & \\
Female & 2 & 4 & 6 \\
\hline
\end{tabular}

Below are the examples of women giving compliments about the appearance and personality found through season 8 .

\section{Data 10}

Jon (Male) Daenerys (Female)

Jon : Queen Daenerys of House Targaryen. My sister Sansa Stark the Lady of winterfell.

Daenerys : Thank you for inviting us into your home, Lady Stark. The North is as beautiful as your brother claimed, as are you.

Sansa : Winterfell is yours, your grace.

This conversation happened when Daenerys came to Winterfell for the first time. It is obvious that Daenerys compliments Sansa on her appearance to establish solidarity. Daenerys' intention to come to Winterfell is to join the war and get its society's heart for she will be their queen. Following the previous research about compliments by Coates (2004), women love to be complimented. As in Data 10, Sansa responded to Daenerys's compliment by smiling. It is a sign of acceptance from Sansa that she is beautiful.

\section{Data 12}

Tyrion (Male) Bran (Male)

Tyrion : This is clever. Even better than the saddle, I designed for you.

Bran : It's the same as the one Daeron Targaryen built for his crippled nephew 120 years ago. I liked that one.

Tyrion : You know our history better than anyone. That would be useful for the Lord of Winterfell.

Bran : I'm not Lord of Winterfell 
The above conversation is talking about Bran's wheelchair as he is a cripple. Tyrion has ever designed a chair for Bran but it seems that Bran's new design is more sophisticated. However, Tyrion continues complimenting Bran about his ability to know history. Bran responded to Tyrion 's compliment by avoiding self-praise. However, he admits that the chair is more sophisticated.

From those conversations, it is clear that the difference of gender in giving compliments is based on the topic. In this small amount of data, women are more likely to complain about physical appearance and personality while men are more likely to compliment the skill and achievements of the characters. Based on the data, high-status male characters are more likely to be complimented than high-status female characters as asserted by Coates (1998). However, the result might be different with the bigger number of data.

\subsection{Minimal Response}

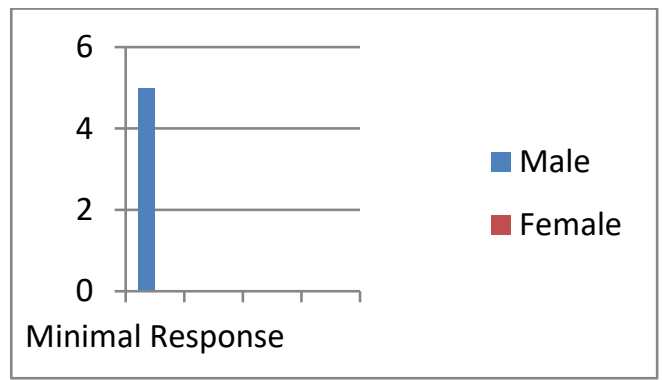

Figure 3. Minimal Response in the conversation of Game of Thrones Season 8

As shown in the diagram, the researcher finds only a few minimal responses throughout Season 8. Interestingly, only male characters use minimal responses in the conversation. Again, the previous stereotype about women making more minimal responses did not match the data of the current study.

There is a notion that women tend to give a minimal response because they are listening more rather than speaking in the conversation (Eriksson, 2008). However, this notion does not seem to appear in this movie. Based on the chosen data, there are only five minimal responses throughout Season 8 of Game of Thrones. Interestingly, no female characters give a minimal response in conversation. Also, the researcher has difficulty finding minimal response in the cross-sex conversation. There is only one minimal response in the cross-sex conversation and the four remaining are minimal responses in the same-sex conversation between male characters. Here are the dialogues of men giving minimal responses:

\section{Data 18}

Jaime (Male) Tyrion (Male)

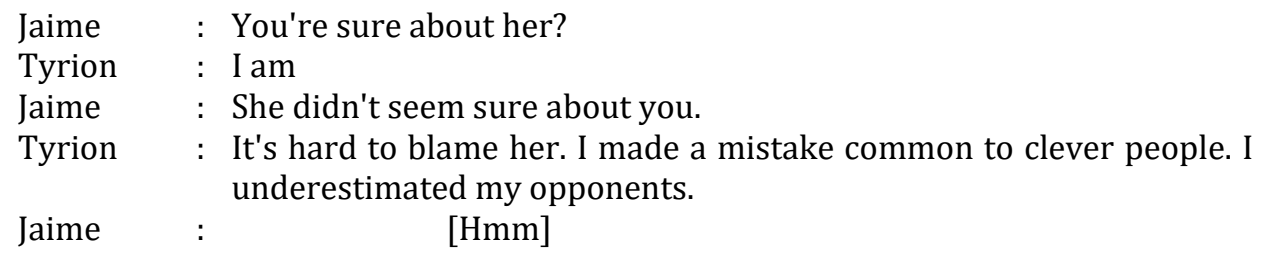


Data 18 is an example of minimal response functioned as a statement of agreement. Here, Jaime agrees that Tyrion is excessively underestimating his opponent who is his sister Cersei. This is a conversation between brothers who have a good relationship. The researcher assumes that they support each other by giving a minimal response. The relationship between speakers must be taken into consideration for it is an important aspect that affects the way they speak in the conversation. This conversation below is also an example of minimal responses functioning as an agreement between friends. Coates (1998) carried out the misunderstanding between male and female minimal responses since they have a different interpretation. Unfortunately, due to the limited data of minimal response, this research cannot go further to that point.

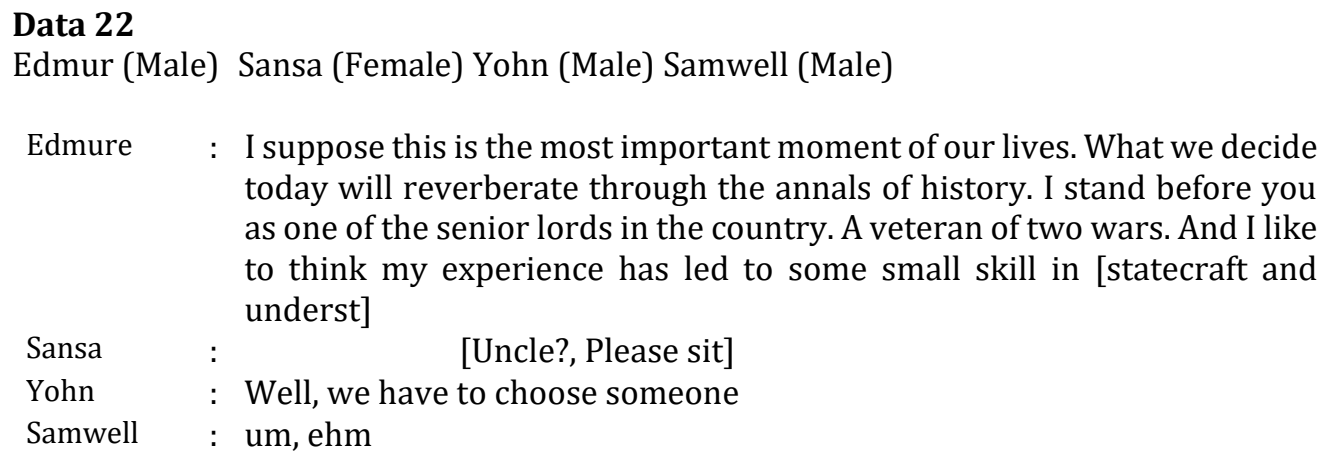

In this conversation, Sam gives a minimal response to Yohn who proposes an idea about choosing the King. It shows that Sam's response is a sign that he is listening to Yohn.

In conclusion, the minimal response used by the characters is to build solidarity and give a short agreement response to the interlocutors. It can be accepted that women in this season never give minimal response since they are all talkative and have high involvement in every conversation. This movie conveys a message that both women and men can use specific gender linguistics features.

\section{Conclusion}

Twenty-two conversations were chosen from Game of Thrones Season 8 to analyze gender conversational style features. The aim was to investigate the representation of the conversational style of the characters in the movie and find out how power plays a role in shaping their linguistic behavior.

The results show that gender conversational features are universal. Some features that are believed to be feminine styles are actually used more frequently by male characters and features believed to be men's styles used more by women as proven in the data. Those features are interruptions, compliments, and minimal responses. From the four features, there is only one feature, which is talkativeness that possibly confirms previous theory. Female characters in this case tend to be interested in a serious discussion rather than the emotional matter. It is because of their role in the movie. They are highly social status women, and the researcher's best analysis is they wanted to be bold and preserve their dignity. Interrupting is believed to be men's behavior but it does not seem to be represented this way in this current study as female characters in power were found to interrupt more during the discussions. In addition, compliments and minimal responses acknowledged to be female's features are mostly used by male characters. The way each gender compliments is different in terms of topics. For the last feature, the current data shows that there is no minimal response made by female characters. 
It is because females appear to be talkative and have a high level of involvement in every conversation.

This study has gone some way towards enhancing our understanding of how language style is universal even in the movie representation. These results might not be applicable to all seasons of Game of Thrones since the characters and setting are different following the storyline. In this season, all female characters are holding an important role and this characteristic brings impact to the result of this study. Not only gender that influenced the conversation, but also the relation between male and female characters, and the power. As such, further study can explore other seasons in order to have a comparative analysis particularly on male-female construction.

\section{References}

Bjorkqvist, K., \& Niemela, P. (Eds.). (1992). Of mice and women: Aspect of female aggression. San Diego: Academic Press.

Bonvillain, N. (2007). Women and men: Cultural constructs of gender. New Jersey: Pearson Prentice Hall.

Bucholtz, M. (2003). Theories of discourse as theories of gender: Discourse analysis in language and gender studies. In J. Holmes \& M. Meyerhoff (Eds.), The Handbook of Language and Gender (pp. 43-68). Oxford, UK: Blackwell Publishing Ltd. https://doi.org/10.1002/9780470756942.ch2

Carli, L. L. (1990). Gender, language, and influence. Journal of Personality and Social Psychology, 59(5), 941951. https://doi.org/10.1037/0022-3514.59.5.941

Coates, J. (1998). Language and gender: A reader. Massachusetts: Blackwell Publisher Ltd.

Coates, J. (2004). Women, men, and language: A sociolinguistic account of gender differences in language (3rd ed). Harlow, England ; New York: Pearson Longman.

Creswell, J. (2014). Research design: Qualitative, quantitative, and mixed methods approaches (Illustrated). California: SAGE.

DeFrancisco, V., \& Palczewski, C. (2007). Communicating gender diversity: A critical approach. Los Angeles: SAGE.

Eriksson, L. (2008). Gender specific features of language: Their representation in a popular TV show. Retrieved from http://urn.kb.se/resolve?urn=urn:nbn:se:miun:diva-8557

Fitzpatrick, M., Mulac, A., \& Dindia, K. (1995). Gender-preferential language use in spouse and stranger interaction. Journal of Language and Social Psychology, 18-39. https://doi.org/doi:10.1177/0261927x95141002

Gu, L. (2013). Language and gender: Differences and similarities. Atlantis Press.

Hannah, A., \& Murachver, T. (1999). Gender and conversational style as predictors of conversational behavior. Journal of Language and Social Psychology, 18(2), 153-174. https://doi.org/10.1177/0261927X99018002002

Herbert, R. K. (1990). Sex-based differences in compliment behavior. Language in Society, 19(2), 201-224. https://doi.org/10.1017/S0047404500014378.

Holmes, J. (2013). An introduction to sociolinguistics (4. ed). London: Routledge.

IMDb. (n.d.). Retrieved from Game of Thrones website: https://www.imdb.com/title/tt0944947/

Krauss, R. M., \& Chiu, C.-Y. (1998). Language and social behavior. In The handbook of social psychology, Vols. 12, 4th ed (pp. 41-88). New York, NY, US: McGraw-Hill.

Lakoff, R. (1973). Language and woman's place. Language in Society, 2(1), 45-80.

Litosseliti, L. (2006). Gender and language: Theory and practice. London \& New York: Hodder Arnold.

Louazani, K. (2015). Gender linguistic behavior complaining for men vs women: Case study of Tlemcen speech community (Thesis). Retrieved from http://dspace.univ-tlemcen.dz/handle/112/7887

McElhinny, B. (2014). Theorizing gender in sociolinguistics and linguistic anthropology: Toward effective interventions in gender inequity. In The Handbook of Language, Gender, and Sexuality: Second Edition (pp. 48-67). https://doi.org/10.1002/9781118584248.ch2 
Muhammad. (2011). Metode penelitian bahasa. Yogyakarta: Ar-ruzz Media.

Rahayu, B. D. (2018). Breaking gender stereotypes: Daenerys` leadership in Game of Thrones Season 2 (Bachelor Thesis, Sanata Dharma University). Retrieved from https://repository.usd.ac.id/31687/

Shank, G. (2002). Qualitative research. A personal skill approach. New Jersey: Merril Prentice Hall.

Shopi, M. (2015). Linguistics and women's speech. Journal of Educational and Social Research, 5(1 S1), 127.

Shrum, L. J. (2002). Media consumption and perceptions of social reality: Effects and underlying processes. In LEA's Communication Series. Media effects: Advances in theory and research, 2nd ed (pp. 69-95). Mahwah, NJ, US: Lawrence Erlbaum Associates Publishers.

Sunderland, J. (2006). Language and gender: An advanced resource book (1st ed.). Routledge. https://doi.org/10.4324/9780203456491

Suyapit, F. (2017). Gender differences in conversational style at FKIP UMSU (Thesis). Retrieved from http://repositori.umsu.ac.id/xmlui/handle/123456789/4242

Tannen, D. (2005). Conversational style: Analyzing talk among friends. New York: Oxford University Press.

Thorne, B., \& Henley, N. (1975). Language and sex: Difference and dominance. Rowley: Newbury House.

Valeeva, A. (2014). Linguistic behavior as a social and cultural potential in the multiethnic community. Procedia - Social and Behavioral Sciences, 149. https://doi.org/10.1016/j.sbspro.2014.08.329

Wardhaugh, R., \& Fuller, J. (2015). An introduction to sociolinguistics (7th ed.). West Sussex: Blackwell.

Wodak, R. (Ed.). (1997). Gender and discourse. London. https://doi.org/10.4135/9781446250204

Zimmerman, D. H., \& West, C. (1975). Sex roles, interruptions and silences in conversation. Rowley: Newbury House. 